\title{
Study Identification of Some Species of Fish Using the Partial Fragment of Mitochondrial Cytochrome Oxidase Subunit-1Gene (COI) in Danau Panggang, South Borneo
}

\author{
Tuah Nanda Merlia Wulandari ${ }^{1,2^{*}}$ and Aroef Hukmanan Rais ${ }^{1,2}$ \\ ${ }^{1}$ Research Center of Fisheries Public Waters and Fisheries Extension, BRSDM KKP Palembang 30111 \\ Indonesia \\ ${ }^{2}$ Inland Fisheries Resources Development and Management Department, Southeast Asian Fisheries \\ Development Center, Jl. Gub. H.A. Bastari 08 Palembang 30252 Indonesia
}

*Correspondence :

wulandari.tnm@gmail.com

Received : 2020-12-31

Accepted : 2021-03-25

Keywords :

DNA Sequencing, Filogenetic Tree, Genetic Distance, Danau Panggang

\begin{abstract}
Danau Panggang is a unique habitat for fish species used for food and economic purposes that live in it. This study aims to identify several important and endangered fish species in Danau Panggang using the DNA sequence method and water quality in Danau Panggang. The DNA sequence was then aligned with the RefSeq from the GenBank data library by using the BLAST program of NCBI to find the closest identity associated with several types of fish samples being analyzed. The sequence analysis of the DNA show that some fish species analyzed have specific identifications :Trichopodus pectoralis, Phalacronotus apogon, Belodontichthys dinema, Anabas testudineus, and Leptobarbus hoevenii. Based on the results of the phylogenetic tree, it is also found that the relationship between fish taxons in flooded swamps of Danau Panggang is close to one another.
\end{abstract}

\section{INTRODUCTION}

Flooded swamps are the largest resource to support the economy, and one example of economic activities is through capture fisheries resources. Capture fisheries activities are one of the potentials and superiorities for the people of Hulu Sungai Utara Regency in developing swamplands for the welfare of the community (Rais et al., 2019).

The identification of species morphology also has several limitations (Elvyra et al., 2020). Fish of native species and within the same species differ in body shape, color, and growth rate, as found in the climbing perch. Morphological identification observations continue to be used to differentiate between the climbing perch of different origins. Moreover, mitochondrial DNA-based identification systems (mt) offer higher precision in the identification of species or lineages that include amplification and sequencing of short cytochrome C oxidase subunit I (COI) mitochondrial genes (Parvez et al., 2020).

The information on the identification of phylogenetic characters between species and populations is closely related because mitochondrial DNA develops faster than most core genes (Kocher and Stepien, 1997). However, information regarding fish identification using DNA sequences in the waters of Danau Panggang is still minimal, so it is necessary to study fish identification using DNA sequences in Danau Panggang, South 
Kalimantan. Genetic research on the genetic conservation of Betok fish (Anabas testudineus) in the swamp waters of South Kalimantan has been carried out by Slamat et al. (2012). Research on the identification of several types of fish with DNA sequences in the flooded swamps of Danau Panggang aims to obtain a more definite identification based on information on the nucleotide sequences of fish species so that information about the phylogenetic relationships of species among fish taxons in the flooded swamps of Danau Panggang, South Kalimantan can be obtained.

\section{METHODOLOGY}

\section{Place and Time}

This research study identified several selected fish species obtained from the catch of fishermen who used nets in fishing in Danau Panggang, South Kalimantan (Figure 1). Sampling was conducted in October 2016 (Figure 2).

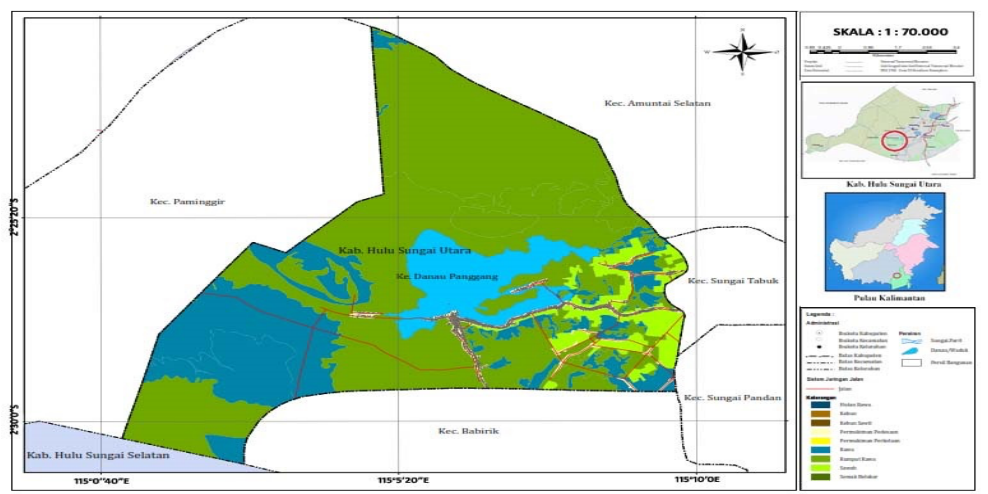

Figure 1. Research location in Danau Panggang, South Kalimantan.

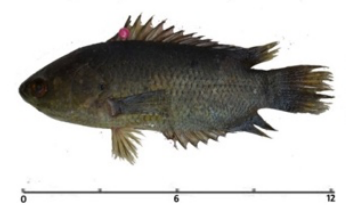

Anabas testudineus (Local name: Papuyu)

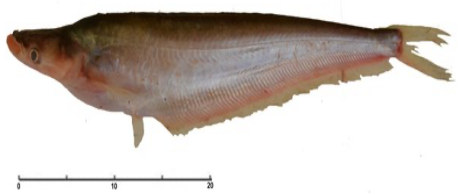

Phalacronotus apogon (Local name: Lais bamban)

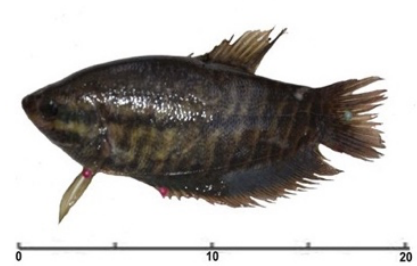

Trichopodus pectoralis (Local name: Sepat siam)

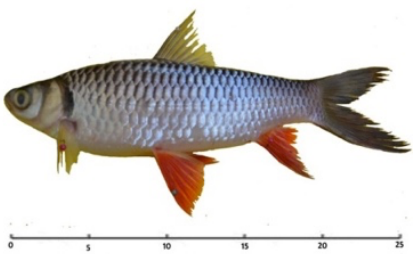

Leptobarbus hoeveni

(Local name: Jelawat)

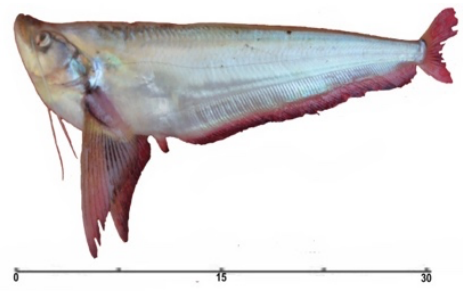

Belodontichthys dinema (Local name: Lais tabirin)

Figure 2. Samples of fish species samples obtained in Flooded Swamps of Danau Panggang, South Kalimantan.

\section{Research Materials}

The tools used in this study were $1000 \mu$ micropipettes (Abdos) along with $1000 \mu \mathrm{l}$ tips (Abdos), $200 \mu \mathrm{l}$ micropipettes (Abdos) along with $200 \mu$ lips (Abdos), 2$10 \mu \mathrm{l}$ micropipettes (Abdos) along with 10 $\mu$ lips (Abdos), digital scales (Mettler), measuring flasks (Duran Schot), vortex (Genie), a centrifuge (Thermo), a PCR machine (BIOER), an electrophoresis machine, an incubator (Ecocell), $1.5 \mathrm{ml}$ tubes (Abdos), $2 \mathrm{ml}$ PCR Plates (Thermo), 
a microwave (Panasonic), a UV Gel doc transiluminator (Alpha imager), measuring cups (Iwaki), gloves (Nitrile), and masks (Sensimask).

The materials used in this study were Genomic DNA kits (Geneaid), florosafe (First Base), myTaq red mix (Bioline), agarose (First Base), 99\% absolute ethanol (Merck), nuclease water (First Base), PCR Purification Clean up (Bioline), Proteinase K (Geneaid), STE (First Base), SDS 10\% (First Base), forward and reverse primers COI (IDT), DNA ladder III markers 100bp ( Geneaid), loading dye (Geneaid), $5 \mathrm{x}$ TBE (First Base), 1x TBE (First Base), and ethidium bromide (Invitrogen).

\section{Research Design}

Each tissue of fish sample obtained was inserted into a $1.5 \mathrm{ml}$ tube filled with absolute ethanol (Merck, 99.9\%) and was given a sample code. DNA sequence identification is a species identification technique that only requires a small amount of fish body tissue using the mitochondrial gene cytochrome oxidase subunit I (COI) (Wulandari et al., 2018). The selected fish samples used as specimens were subjected to laboratory analysis by molecular analysis at the Fish Laboratory, molecular taxonomy section of the Public Aquatic Fisheries Research and Fisheries Extension Center, Palembang. The research was carried out experimentally in the laboratory including, DNA extraction, amplification, electrophoresis, purification of PCR products, and sequencing processes. Samples of purified PCR products were sent to Macrogen Biotechnologies Co., Ltd, Seoul, South Korea for sequencing. The method that could be used to find out genetic information and obtain the sequence of nucleotide bases on a DNA molecule could be done with DNA sequencing (Sanger et al., 1977).

\section{Work Procedure}

DNA samples were extracted from fish tissue samples by referring to the
Genomic DNA mini kit (Geneaid) procedure. The steps of the work procedure included DNA extraction, amplification, purification of PCR products, and DNA sequencing, described as follows:

\section{MtDNA Extraction}

The coded fish tissue DNA samples were extracted using a genomic DNA mini kit for tissue (Geneaid). Fish tissue samples stored in $99 \%$ absolute ethanol (Merck) were washed with distilled water (molecular grade) twice and were then suspended in an STE buffer (First Base) up to a volume of $250 \mu \mathrm{l}$. Muscle tissue of the fish was lysed (broken/removed) with SDS (Firstbase, 10\%) as much as $50 \mu \mathrm{l}$ and proteinase $\mathrm{K}$ (Geneaid) as much as $20 \mu \mathrm{l}$ and then put in an incubator (Ecocell) at a temperature of $42^{\circ} \mathrm{C}$ for 14 hours. The DNA extraction method later follows the instructions for the genomic DNA mini kit for tissue (Geneaid).

\section{Amplification}

Amplification used COI (Integrated DNA Technologies) primers to amplify DNA sequences. Some fragments of the mitochondrial COI gene were amplified using universal primers based on Ivanova et al. (2007): Fish COI-F (5'ACT TCA AAC TTC CAY AAA GAY ATY GG-3 ') and COIFish-R (5'- TAG ACT TCT GGG TGG CCR AAR AAY CA-3 '). The composition of the PCR reaction was carried out with a final volume of $50 \mu \mathrm{l}$ consisting of $2 \mu \mathrm{l}$ of DNA samples, $21 \mu \mathrm{l}$ of sterile nuclease water (Firstbase), primer of $1 \mu \mathrm{l}$ each and also the addition of $25 \mu \mathrm{l}$ of PCR premix (My Taq Bioline red mix). The PCR reaction was carried out using a thermocycler (BIOER) machine with the following conditions: the pra-denaturation stage at a temperature of $95{ }^{\circ} \mathrm{C}$ for 1 minute, the second stage consisting of 35 cycles which included a denaturation stage at temperature of $95{ }^{\circ} \mathrm{C}$ for 15 seconds for each cycle, the primary attachment (annealing) at a temperature of $55{ }^{\circ} \mathrm{C}$ for 15 seconds, extension at a temperature of 
$72{ }^{\circ} \mathrm{C}$ for 30 seconds, and the last stage in the form of final extension at a temperature of $72{ }^{\circ} \mathrm{C}$ for 3 minutes and the introduction to renaturation at a temperature of $6{ }^{\circ} \mathrm{C}$ for 6 minutes (Wulandari et al., 2019).

\section{Electrophoresis}

Electrophoresis was carried out on PCR products to be tested using agarose gel (Firstbase) which was previously added with $10 \mu \mathrm{l}$ of ethidium bromide (Invitrogen) in 10x TBE (Firstbase, 1\%) buffer. Following this, the gel was poured into gel molds that were ready to be injected into each well of $2 \mu \mathrm{l}$ of PCR DNA samples according to the sequence of sample numbers, negative control, positive control and $5 \mu \mathrm{l}$ markers. Afterward, the electrophoresis process was carried out at conditions of $120 \mathrm{v}, 250 \mathrm{~A}$ for 35 minutes. After the electrophoresis had been completed, the gel was put into gel documentation (Protein Simple Alpha Imager), and the gel doc UV lamp was turned on. The analysis of the presence of DNA bands was done by comparing ladder III 100 bp (Firstbase) DNA markers, positive control, and negative control (Wulandari et al., 2019).

\section{Purification of PCR products}

PCR products on agarose gel set in size according to the primary design were purified using a purification kit (Bioline isolate II PCR and gel) following the manufacturer's protocol.

\section{Data Analysis}

The results of the nucleotide sequences were then manually edited using Bioedit software based on a chromatogram (Hall, 1999). The edited nucleotide sequences were then aligned using Clustal W (Thompson et al., 1997) using the MEGA 6.0 program (molecular evolutionary genetics analysis) (Tamura et al., 2013). The DNA sequences were then aligned with the reference sequences from the gene bank data library from NCBI using the BLAST application to find the identity that was most closely related to the type of fish sample analyzed.

\section{RESULTS AND DISCUSSION}

DNA isolation of several types of fish in Danau Panggang was amplified using a pair of universal primers, Fish-COI-F and COI-Fish-R based on Ivanova et al. (2007) which was then continued with electrophoresis observed from the formation of DNA bands on the UV transilluminator (Figure 2). Initially, DNA extracts of fish tissue were taken from 22 fish species and were amplified on the 530bp target DNA fragment, but only 16 fish specimens were successful. The identification of several fish species using DNA sequences was carried out on 16 fish samples and five NCBI Genbank as comparisons. The amplification of the cytochrome oxidase subunit I (COI) gene produced a COI gene fragment measuring 640-702 bp.

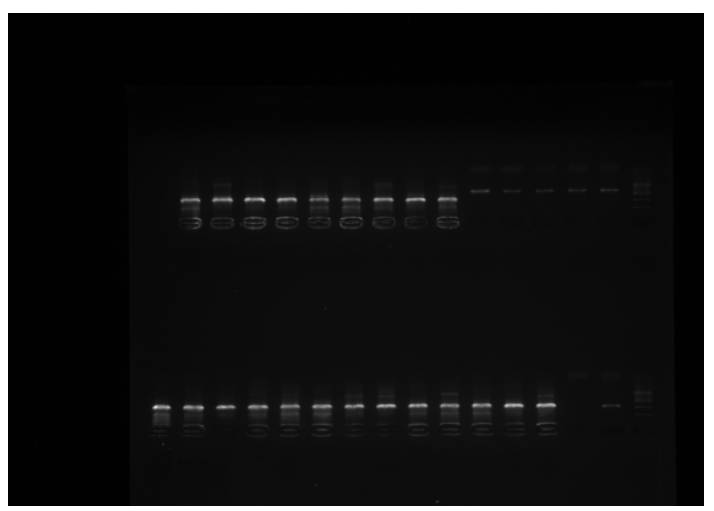

Figure 3. A photo of fish COI-F and COI-Fish-R gel electrophoresis amplification. 


\section{DNA Sequencing}

The mitochondrial cytochrome $\mathrm{c}$ oxidase I (COI) gene serves as the core of a global bio-identification system for animals and aids the diversity resolution (Hebert et al., 2003).

Based on the results of BLASTN gene sequences of partial mitochondrial cytochrome oxidase subunit I (COI) genes, the fish species analyzed on a molecular basis as a whole have similarities ranging from $89 \%$ to $100 \%$ (Table 1 ). Fish with
EC08 FCOI samples have 89\% similarity with $P$. apogon (voucher FNP108), ED07 FCOI has $94 \%$ similarity with $L$. hoevenii (voucher YR033701), EA08FCOI and EB08FCOI have $100 \%$ similarity with $T$. pectoralis (voucher Tpec1). Fish with sample code EH07 FCOI, EG07 FCOI, ED08 FCOI have $100 \%$ similarity with $B$. dinema (voucher SLM-BD (PH) -01), and the other nine fish samples have 99\% similarity with $A$. testudineus (voucher BIF2107).

Table 1. Results of BLASTN of fish species in the flooded swamps of Danau Panggang, South Kalimantan.

\begin{tabular}{|c|c|c|c|c|c|}
\hline \multirow{2}{*}{\multicolumn{3}{|c|}{$\frac{\text { Sample }}{2 \cdot \text { FA0 }}$}} & \multirow{2}{*}{$\frac{\text { Species }}{\text { Trichopodus pectoralis }}$} & \multirow{2}{*}{$\frac{\% \text { Identity }}{100 \%}$} & \multirow{2}{*}{$\begin{array}{l}\text { Access No. } \\
\text { KX817191.1 }\end{array}$} \\
\hline & & & & & \\
\hline EE07 & FCOI; EF07 & FCOI; & Anabas testudineus (voucher & $99 \%$ & KU692243.1 \\
\hline EA09 & EB09 & FCOI; & BIF2107) & & \\
\hline EC09 & FCOI; EE08 & FCOI; & & & \\
\hline EF08 & FCOI; EG08 & FCOI; & & & \\
\hline \multicolumn{6}{|c|}{ EH08 FCOI } \\
\hline \multicolumn{3}{|c|}{$\begin{array}{l}\text { EH07 FCOI; EG07 FCOI; } \\
\text { ED08 FCOI }\end{array}$} & $\begin{array}{l}\text { Belodontichthys dinema } \\
\text { (voucher SLM-BD(PH)-01) }\end{array}$ & $100 \%$ & JF781186.1 \\
\hline \multicolumn{3}{|c|}{ EC08 FCOI } & $\begin{array}{l}\text { Phalacronotus apogon } \\
\text { (voucher FNP108) }\end{array}$ & $89 \%$ & MK448160.1 \\
\hline \multicolumn{3}{|c|}{ ED07 FCOI } & $\begin{array}{l}\text { Leptobarbus hoevenii (voucher } \\
\text { YR033701) }\end{array}$ & $94 \%$ & KC242349.1 \\
\hline
\end{tabular}

The percentage of the nucleotide composition of fish species analyzed based on molecular sequencing on the four fish species, namely $P$. apogon, B. dinema, A. testudineus, and $L$. hoevenii has a DNA G + $\mathrm{C}$ base composition that is higher than the base composition of DNA A $+\mathrm{T}$, whereas fish with the species $T$. pectoralis $(\mathrm{n}=2)$ have a lower $\mathrm{G}+\mathrm{C}$ composition than the composition of $\mathrm{A}+\mathrm{T}$. The value of the composition of the $\mathrm{G}+\mathrm{C}$ content is higher in the nucleotide, which means it is more difficult for the double-stranded DNA molecules to separate (Yuwono, 2008). A. testudineus COI nucleotide sequences taken from the NCBI Bank genes in India, Thailand, and Vietnam were analyzed with higher AT content (53.6\%) and lower GC content (46.4\%) (Parvez et al., 2020). The percentage composition of the nucleotide species of fish analyzed by molecular analysis is presented in Table 2 .

Table 2. Percentage of nucleotide composition.

\begin{tabular}{clcc}
\hline \multirow{2}{*}{ No } & \multicolumn{1}{c}{ Sample } & \multicolumn{2}{c}{ Composition of Nucleotides } \\
& & G+C $(\%)$ & A+T (\%) \\
\hline 1 & Trichopodus pectoralis $(\mathrm{n}=2)$ & 48.9 & 51.1 \\
2 & Anabas testudineus $(\mathrm{n}=9)$ & 54.5 & 45.5 \\
3 & Belodontichthys dinema $(\mathrm{n}=3)$ & 54.8 & 45.2 \\
4 & Phalacronotus apogon $(\mathrm{n}=1)$ & 54.0 & 46.0 \\
5 & Leptobarbus hoevenii $(\mathrm{n}=1)$ & 52.0 & 48.0 \\
\hline
\end{tabular}

\section{Phylogenetic Tree and Genetic Distance}

The molecular marker, region 570 bp of the mitochondrial cytochrome $\mathrm{c}$ oxidase I (COI) gene, has been successful 
in finding specific species, and it is also found that there are more variations between species than within species (Wibowo and Merlia, 2017). This research is an important step to understand the kinship of fish living in the flooded swamps of Danau Panggang in South Kalimantan. The creation of COI sequences from the Danau Panggang system also supports the global DNA barcode libraries.

The identification of DNA sequences results in five types of fish. The DNA sequences were then aligned with the RefSeq from the GenBank data library to see the phylogenic tree using the BLAST program from NCBI to find the identities that are most closely related to the analyzed fish samples. In general, the position of phylogenetic tree organisms is based on genetic similarities between one species and another. The five types of fish are obtained from the catch of fishermen in the flooded swamps of Danau Panggang, South Kalimantan, including $T$. pectoralis, $P$. apogon, B. dinema, A. testudineus, and $L$. hoevenii (Figure 2 ). The position of organisms on the phylogenetic tree shows the close kinship between adjacent taxons. Organisms of different species of the same genus will be close to each other in trees, and the further distance in the phylogenetic tree is found in different genera (Wulandari et al., 2019).

A. testudineus belongs to the Anabantidae family (one of the 30 species in this family) and is the main component of ichthyofauna Sundaland. This species is widely distributed in Africa and Asia and is the only member of the Anabantidae family in Asia. A. testudineus is one of the foreign fish species scattered in the waters of Sulawesi and Sundaland (Weber and de Beaufort, 1922; Kottelat and Whitten, 1996; Hubert et al., 2015). However, the actual data on their occurrence or even impacts on native fauna are very limited and scattered in literature.

The collection of basic genetic information and data on a species is an initial condition needed to determine its kinship (Nugroho et al., 2003). Molecular species identification techniques have the potential for rapid and precise labeling assessment (Wong et al., 2011). The COI gene sequence produced in the $T$. pectoralis sample in the flooded swamps of Danau Panggang ranges from 510 bp-585 bp. Research by Syaifudin et al. (2019) states that the resulting $T$. pectoralis COI gene sequence is at $604 \mathrm{bp}$ and has $100 \%$ similarity to the same species in Indonesia and the Philippines.

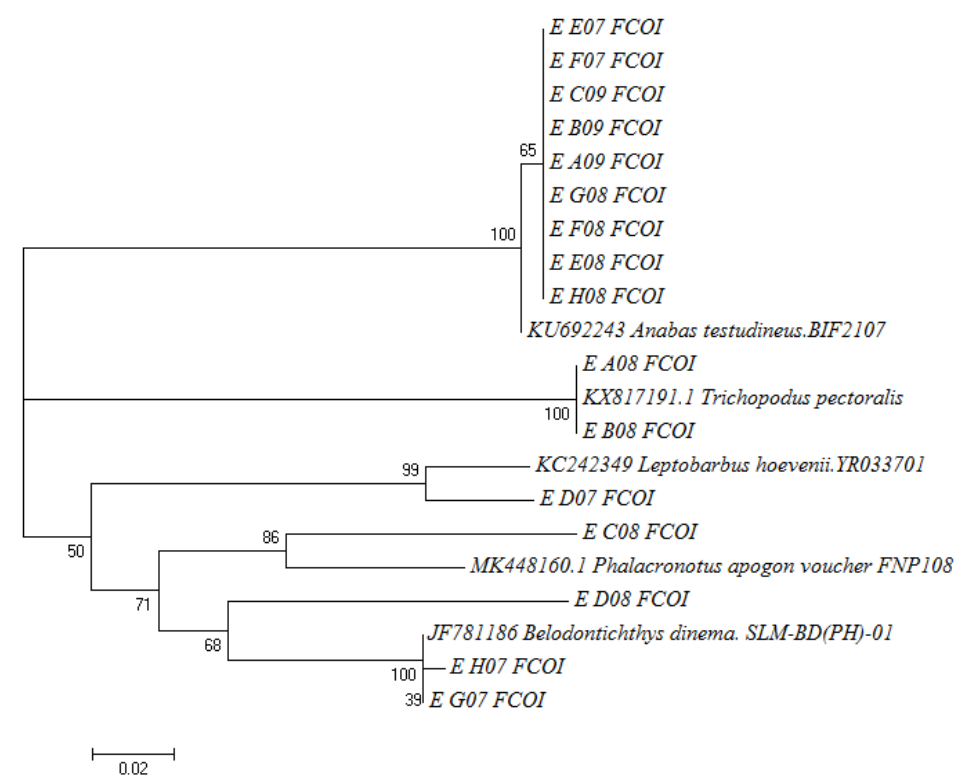

Figure 4. Analysis of neighbor-joining trees from COI sequencing of fish in Danau Panggang, South Kalimantan. 
Gene sequencing (DNA sequencing) for phylogenetic analysis is rarely performed because the cloning of homologous genes from several samples still needs high cost (Kocher and Stepien, 1997). The COI profile correctly identifies the specimen. When the identification systems using COI are fully developed, they can provide reliable, cost-effective, and accessible solutions to current species problems (Hebert et al., 2003).

The introduction of primary sequences with broad phylogenetic uses such as with the use of universal primers allows the rapid amplification of a specific sequence from a large number of samples and helps to create a rapid number of studies using DNA sequences to examine phylogenetic questions (Kocher and Stepien, 1997). DNA sequencing data has several inherent advantages over other types of systematic data. First, an unlimited number of potentially available sequence characters. Second, this character is useful for studying the relationship between close and distant relatives. Based on the phylogenetic tree, evolutionary relationships are obtained between several fish species, genera and families. Organisms of different species of the same genus will be adjacent to each other in the phylogenetic tree.

Table 3. Average genetic distances between groups of fish species.

\begin{tabular}{lcccc}
\hline Name of Fish Species & 1 & 2 & 3 & 4 \\
\hline Trichopodus pectoralis & & & & \\
Phalacronotus apogon & 0.264 & & & \\
Belodontichthys dinema & 0.291 & 0.170 & & \\
Anabas testudineus & 0.262 & 0.248 & 0.229 & \\
Leptobarbus hoevenii & 0.234 & 0.215 & 0.199 & 0.254 \\
\hline
\end{tabular}

The most common analysis used to estimate genetic distance values is the genetic distance (Nei, 1972; Kocher and Stepien, 1997). The phylogenetic relationship was deduced from this distance using the Neigbour-Joining method (Saitou and Nei, 1987). The result of measuring the genetic distance was an evolutionary estimate of the scatter among the fish group sequences. The number of base substitutions per site from the mean of all sequences between groups was later shown. Moreover, the analysis was performed using a 2-parameter Kimura model using the MEGA6 program (Kimura, 1980; Tamura et al., 2013). The analysis was performed on 21 nucleotide sequences. Codon positions included the first, second and third positions. All positions had gaps and the lost data could be eliminated.

The nucleotide sequence data were compared by aligning them with each other and checking for differences. Closely related taxa would have few differences, and these differences were easy to find and evaluate, whereas for far related taxa larger differences would be noticeable, which could even make alignment impossible (Beaumont et al., 2010).

Organisms of different species and genera have longer distances, such as in the phylogenic trees of $T$. pectoralis, $P$. apogon, $B$. dinema, $A$. testudineus and $L$. hoevenii than in other groups with node spacing ranging from 0.170 to 0.254 (Table 3). The NJ estimate and the bootstrap estimate in this study show the minimum genetic distance (0.262) between these two species ( $T$. pectoralis and $A$. testudineus) which emphasizes the evolutionary relationship as well as their recent differences. When the order of individual fish is compared with the same species, it shows that the profile is almost the same. Therefore, it can be concluded that the population of each species is almost homogeneous (Meffe and Vrijenhoek, 1988). The average genetic distance between fish species is found to be high enough, showing a separate gene pool for these species. 


\section{CONCLUSION}

Organisms of different species and genera have longer distances, such as in the phylogenic trees of Trichopodus pectoralis, Phalacronotus apogon, Belodontichthys dinema, Anabas testudineus and Leptobarbus hoevenii than in other groups with node spacing ranging from 0.170 to 0.254

\section{ACKNOWLEDGMENT}

This Scientific Writing is a contribution from research activities at the Research Center of Fisheries Public Waters and Fisheries Extension, Palembang. The authors would like to thank Prof. Agus Djoko Utomo, Mr. Ir. Samuel, Mr. Dr. Arif Wibowo, Mrs. Ir. Siti Nurul Aida, M. P. and Mr. Herlan, S.P. (BRPPUPP), for their guidance and knowledge transfer for the accomplishment of this research and writing.

\section{REFERENCES}

Beaumont, A., Boudry, P. and Hoare, K., 2010. Biotechnology and genetics in fisheries and aquaculture. John Wiley \& Sons.

Elvyra, R., Solihin, D.D., Affandi, R., Junior, M.Z. and Suhendra, M., 2020. Short Communication: Molecular Characteristics And Phylogenetic Relationships Of Silurid Catfishes (Kryptopterus, Ompok And Phalacronotus) From The Kampar River, Indonesia, Based On The Cytochrome B Gene. Biodiversitas Journal of Biological Diversity, 21(8), pp.3539-3546. https://doi.org/10.13057/biodiv/d 210816

Hall, T.A., 1999. BioEdit: a user-friendly biological sequence alignment editor and analysis program for Windows 95/98/NT. Nucleic Acids Symposium Series, 41(2), pp.95-98. https://academic.oup.com/nass/iss ue/42/1

Hebert, P.D.N., Ratnasingham, S. and de Waard, J.R., 2003. Barcoding animal life: cytochrome $c$ oxidase subunit 1 divergences among closely related species. Proceedings of the Royal Society B Biological Sciences, 270, pp.S96-S99. https://doi.org/1 $0.1098 / \mathrm{rsbl} .2003 .0025$

Hubert, N., Kadarusman., Wibowo, A., Busson, F., Caruso, D., Sulandari, S., Nafiqoh, N., Pouyaud, L., Rüber, L., Avarre, J.C., Herder, F., Hanner, R., Keith, P. and Hadiaty, R.K., 2015. Review : DNA Barcoding Indonesian freshwater fishes: challenges and prospects. DNA Barcodes, 3, pp.144169. https://dx.doi.org/10.1515/dn a-2015-0018

Ivanova, N.V., Zemlak, T.S., Hanner, R.H. and Hebert, P.D.N., 2007. Universal primer cocktails for fish DNA barcoding. Molecular Ecology Notes, 7(4), pp.544-548. https://doi.org/1 0.1111/j.1471-8286.2007.01748.x

Kimura, M., 1980. A simple method for estimating evolutionary rates of base substitutions through comparative studies of nucleotide sequences. Journal of molecular evolution, 16(2), pp.111-120. https: //doi.org/10.1007/BF01731581

Kocher, T.D. and Stepien, C.A. eds., 1997. Molecular systematics of fishes. USA : Academic Press.

Kottelat, M. and Whitten, T., 1996. Freshwater fishes of Western Indonesia and Sulawesi: additions and corrections (p.8). Hong Kong: Periplus editions.

Meffe, G.K. and Vrijenhoek, R.C., 1988. Conservation genetics in the management of desert fishes. Conservation Biology, 2(2), pp.157169. https://doi.org/10.1111/j.152 3-1739.1988.tb00167.x

Nei, M., 1972. Genetic distance between populations. The American Naturalist, 106(949), pp.283-292. https://doi.org/10.1086/282771

Nugroho, E., Hadie, W. and Sudarto, 2003. Variasi genetik ikan baung (Mystus nemurus) dari beberapa Waduk di Jawa yang dianalisis dengan marker mitokondria D-Loop. Jurnal Penelitian Perikanan 
Indonesia, 9(1), pp.1-5. http://dx.d oi.org/10.15578/jppi.9.1.2003.1-5

Parvez, I., Mahajebin, T., Clarke, M.L., Chhanda, M.S. and Sultana, S., 2020. Genetic variation of native and introduced climbing perch Anabas testudineus (Bloch, 1792) derived from mitochondrial DNA analyses. Ecological Genetics and Genomics, 17, p.100067. https://doi .org/10.1016/j.egg.2020.100067

Rais, A.H., Wulandari, T.N.M. and Dharyati, E., 2019. Aktivitas Penangkapan Dan Produksi Ikan Di Kabupaten Hulu Sungai Utara Kalimantan Selatan. Jurnal Penelitian Perikanan Indonesia, 24(4), pp.227-238. http://dx.doi.or g/10.15578/jppi.24.4.2018.227238

Sanger, F., Nicklen, S. and Coulson, A.R., 1977. DNA sequencing with chainterminating inhibitors. Proceedings of the national academy of sciences, 74(12), pp.5463-5467. https://doi. org/10.1073/pnas.74.12.5463

Syaifudin, M., Jubaedah, D., Yonarta, D. and Hastuti, Z., 2019. DNA barcoding of snakeskin gourami Trichogaster pectoralis and blue bourami Trichogaster trichopterus based on cythocrome c oxidase subunit I (COI) gene. IOP Conference Series: Earth and Environmental Science 348(012031). https://doi.or g/10.1088/1755-1315/348/1/0120 31

Saitou, N. and Nei, M., 1987. The neighbor-joining method: a new method for reconstructing phylogenetic trees. Molecular biology and evolution, 4(4), pp.406-425. https://doi.org/10.1093/oxfordjour nals.molbev.a040454

Slamat, S., Marsoedi, M., Mursyid, A. and Arfiati, D., 2016. Konservasi Genetik Ikan Betok (Anabas testudineus Bloch 1792) Di Perairan Rawa, Kalimantan Selatan. Jurnal Penelitian Perikanan Indonesia, 18(1), pp.9-15. http://dx.doi.org/1 0.15578/jppi.18.1.2012.9-15
Tamura, K., Stecher, G., Peterson, D., Filipski, A. and Kumar, S., 2013. MEGA6: molecular evolutionary genetics analysis version 6.0. Molecular biology and evolution, 30(12), pp.2725-2729. https://doi. org/10.1093/molbev/mst197

Thompson, J.D., Gibson, T.J., Plewniak, F., Jeanmougin, F. and Higgins, D.J., 1997. The CLUSTAL $X$ windows interface: Flexible strategies for multiple sequences alignment aided by quality analysis tool. Nucleic Acids Research, 25(24), pp.4876-4882. https://doi.org/10.1093/nar/25.24 .4876

Weber, M. and de Beaufort, L.F., 1922. The Fishes of the Indo-Australian Archipelago:

Heteromi, Solenichthyes, Synentognathi, Percesoces, Labyrinthici, Microcyprini (Vol. 4). EJ Brill Limited.

Wibowo, A. and Merlia, T.N., 2017. Evaluation Of Genetic Relationship Among Select Six Fish Species Using The Partial Fragment Of Mitochondrial Cytochrome C Oxidase Subunit-1gene (CO1). In Proceedings of the $16^{\text {th }}$ World Lake Conference: Lake Ecosystem Health and Its Resilience: Diversity and Risks of Extinction. pp.337-340.

Wong, L.L., Peatman, E., Lu , J., Kucuktas, H., He, S., Zhou ,C., Nakorn, U.N. and Liu , Z., 2011. DNA barcoding of catfish: species authentication and phylogenetic assessment. PLoS One, 6(3), e17812. https://doi.org/10.13 71/journal.pone.0017812

Wulandari, T.N.M., Herlan and Wibowo, A., 2018. Identifikasi Beberapa Spesies Ikan Dengan Sekuens DNA di Danau Cala, Sumatera Selatan. In Prosiding Pertemuan Ilmiah Masyarakat Limnologi Indonesia Tahun 2017, pp.192-197. Bogor, Indonesia: Kongres dan Pertemuan Ilmiah Tahunan III MLI.

Wulandari, T.N.M., Herlan, Wibowo, A. and Sawestri, S., 2019. Identifikasi jenis dan hubungan kelimpahan larva ikan dengan kualitas air di 
Danau Ranau, Sumatera Selatan.

BAWAL, 11(1), pp.33-44. http://dx.

doi.org/10.15578/bawal.11.1.2019

$.33-44$

Yuwono, T., 2005. Biologi Molekuler.

Jakarta: Erlangga. 